\title{
PENGEMBANGAN KOMPETENSI PADA PENDIDIKAN UMUM
}

\section{Prof. Dr. H. Nana Syaodih Sukmadinata}

\begin{abstract}
Kompetensi mempunyai makna yang luas. Minimal dapat dibedakan atas lima macam kompetensi, yaitu kompetensi dasar, kompetensi umum, kompetensi akademis, kompetensi vokasional dan kompetensi profesional. Dalam program pendidikan umum, konsep kompetensi dapat diterapkan namun demikian konsep dan rumusan kompetensinya berbeda dengan yang diterapkan pada program pendidikan vokasional atau kejuruan. Kurikulum dan pembelajarannya diarahkan kepada penguasaan kompetensi atau kemampuan berpikir tahap tinggi. Proses pembelajaran tidak berhenti pada penguasaan pengetahuan (ingatan) dan pengertian (pemahaman), tetapi dilanjutkan kepada tahapan yang lebih tinggi. Menurut Lorin W. Anderson dan David R. Krathwohl (2001) dilanjutkan kepada tahapan aplikasi, analisis (sintesis), evaluasi dan kreativitas. Karena itu, dalam Pendidikan Umum diharapkan digunakan pendekatan-pendekatan pembelajaran yang lebih mengaktifkan siswa, seperti pembelajaran: diskaveri-inkuiri, bermakna, kontekstual, eksperiensial, komunikatif, pemecahan masalah, pengamatan lingkungan, percobaan, penelitian sederhana, simulasi, bermain peran, praktik langsung, dsb.
\end{abstract}

Keywords : Kompetensi, Pendidikan umum, berpikir tahap tinggi

\section{Pendidikan dan kurikulum berbasis kometensi}

Pendidikan yang menekankan kompetensi, sebenarnya bukan hal baru. Pada tahun 1975, Direktorat Jenderal Pendidikan Tinggi telah mengembangkan beberapa panduan bagi pengembangan pendidikan yang berbasis kompetensi di bidang pendidikan guru, khususnya IKIP dan
FKIP. Program pendidikannya dikenal dengan sebutan Pendidikan Guru Berbasis Kompetensi (PGBK), terjemahan dari Competence Based Teacher Education (CBTE) atau Performance Based Teacher Education (PBTE). Karena ada beberapa hambatan dan adnya kebijakan baru, program ini tidak berjalan penuh 
walaupun beberapa prinsip dasarnya tetap dilaksanakan.

Pendidikan berbasis kompetensi (PBK) atau Competence Based Education (CBE) dengan intinya kurikulum berbasis kompentensi (KBK) atau Competence Based Curriculum ( $C B C)$, memang pada mulanya dan banyak digunakan pada pendidikan vokasional, pendidikan kejuruan dan pelatihan-pelatihan. Di lingkungan Sekolah Menengah Kejuruan (SMK), program pendidikan ini, sudah lama dilaksanakan, dan sampai saat ini masih terus diadakan penyempurnaan-penyempurnaan.

Pada pendidikan vokasional atau kejuruan, program pendidikan dan kurikulum berbasis kompetensi ini diarahkan pada pengembangan kompetensi kerja, yaitu penguasaan kemampuan, kecakapan, keterampilan, kebisaan melakukan tugas-tugas pekerjaan.

\section{Macam-macam kompetensi}

Kompetensi tidak selalu berarti kompetensi kerja, sebab kompetensi mempunyai makna yang luas. Minimal dapat dibedakan lima macam kompetensi, yaitu kompetensi dasar, kompetensi umum, kompetensi akademis, kompetensi vokasional dan kom-petensi profesional.

Kompetensi dasar merupakan kemampuan, kecakapan, keterampil- an awal yang perlu dikuasai agar dapat menguasai kompetensikompetensi yang lebih tinggi. Berbicara, membaca, menulis dan berhitung permulaan di kelas satu, merupakan kompetensi dasar bagi penguasaan kompetensi yang lebih tinggi Bicalistung di kelas-kelas selanjutnya, dan Bicalistung merupakan kompetensi dasar bagi penguasaan mata-mata pelajaran IPS, Bahasa, IPA, Matematika, dsb., di SD, SLTP, SLTA dan bahkan Perguruan Tinggi. Kompetensi dasar mencakup juga kemampuankemampuan untuk menjaga, memelihara, dan mengembangkan diri, baik secara fisik, intelektual maupun sosial budaya..

Kompetensi umum merupakan kemampuan, kecakapan, keterampilan yang diperlukan dalam kehidupan, baik dalam keluarga, di sekolah, di masyarakat ataupun di lingkungan kerja. Kecakapan menyeberang di tempat penyebrangan (zebra cross), menghidupkan-mematikan radio dan tv, naik bis umum, naik tangga berjalan, naik lift, menggunakan telepon, menulis surat, mengendarai sepeda atau sepeda motor, merawat kompor, kulkas, mesin cuci, dsb., merupakan contoh-contoh dari kompetensi umum.

Kompetensi vokasional adalah kemampuan, kecakapan, keterampil- 
an, kebiasaan berkenaan dengan penyelesaian tugas-tugas pekerjaan. Hampir semua mata pelajaran yang terkait dengan praktek di Sekolah Menegah Kejuruan, diarahkan pada penguasaan kompetensi vokasional. Sesuai dengan jurusan atau program keahliannya, umpamanya Program Keahlian Elektronika, mempersiapkan para lulusannya dalam penguasaan kompetensi-kompetensi di bidang elektronika, agar nanti mereka dapat bekerja pada berbagai unit bisnis elektronika. Di SLTP bahkan di SD pun ada kalanya telah diberikan pelajaran keterampilan, tetapi kemungkinan besar pada tahap ini belum sampai pada penguasaan kompetensi vokasional, tetapi masih berupa kompetensi pra vokasional.

Kompetensi akademis merupakan kemampuan, kecakapan, keterampilan, kebisaan mengaplikasikan konsep, teori dan prinsip-prinsip ilmu di dalam kehidupan, baik dalam kehidupan di rumah, di masyarakat maupun dalam pekerjaan.

Kompetensi profesional merupakan kemampuan, kecakapan, kebisaan tingkat tinggi, perkembangan lebih lanjut dari kompetensi vokasional maupun akademis. Dalam kompetensi profesional, kemampuan atau kecakapan yang dikuasai sudah sesuai dengan standar yang dituntut oleh suatu profesi. Contoh dari kompetensi profesional, adalah kompetensi dokter, penasihat hukum, akuntan, pilot, dsb.

\section{Kompetensi pada program pendidikan umum}

Apakah PBK dan KBK atau konsep kompetensi dapat diterapkan pada program pendidikan umum seperti SD, SLTP dan SLTA? Jawabannya adalah bisa, namun konsep dan rumusan kompetensinya berbeda dengan yang diterapkan pada program pendidikan vokasional atau kejuruan..

Program pendidikan vokasional diarahkan pada penguasaan kecakapan, keterampilan kerja, atau performansi kerja. Kompetensi atau performansi ini memiliki standar dan kriteria penguasaan sesuai dengan tuntutan dalam bidang pekerjaan, atau vokasi tertentu.

Program pendidikan umum lebih banyak bermuatan ilmu, walaupun pada jenjang SD dan SLTP masih dalam tahap yang sederhana. Program pendidikann ini diarahkan pada penguasaan pengetahuan, pemahaman dan aplikasi dari konsepkonsep dan prinsip-prinsip ilmu yang dipelajarinya. Aplikasi dari konsep dan prinsip-prinsip tersebut masih bersifat terbuka, bisa dalam bidang pekerjaan, kehidupan di masyarakat atau dalam keluarga. Walaupun 
aplikasinya dalam bidang pekerjaan, kompetensi ilmu atau kompetensi tetapi juga masih bersifat umum, umum, yang menjadi fokus utamanya dasar-dasar bagi kecakapan atau adalah aspek kognitif atau berpikir, keterampilan kerja.

Penguasaan pengetahuan, pemahaman dan aplikasi konsep dan prinsip-prinsip ilmu, lebih banyak menyangkut aspek kognitif, aspek intelektual atau kemampuan berpikir. Aspek afektif dan psikomotor juga tercakup, walaupun dalam porsi yang relatif lebih kecil.

Aplikasi suatu konsep atau prinsip ilmu dalam kenyataan (pekerjaan atau kehidupan) akan terlihat dalam bentuk perilaku atau performansi, yaitu berupa serangkaian keterampilan hubungan sosial dan/atau keterampilan motorik. Dengan demikian dalam aplikasi tersebut akan nampak aspek psikomotornya. Perilaku atau performansi (sebagai aplikasi dari konsep atau prinsip ilmu) dalam bentuk rangkaian keterampilan sosial $k$ dan motorik tersebut, apakah dikerjakan dengan penuh kesungguhan, ketekunan dan ketelitian atau dikerjakan asal-asalan. Hal ini sangat terkait dengan aspek afektif, terutama sikap, minat dan nilai. Dengan demikian bidang afektif juga terkait di dalam aplikasi konsep dan prinsipprinsip ilmu tersebut.

Memang ketiga aspek atau ranah perkembangan tersebut, terkait satu sama lain. Pada pengembangan tetapi aspek psikomotor dan afektif juga terkait dan malahan memperkuat. Pada pengembangan kompetensi vokasional, yang menjadi fokus utama adalah psikomotor, tetapi aspek kognitif dan afektif juga terkait dan mendukung.

Gagasan penguasaan kompetensi ilmu berupa aplikasi konsep dan prinsip-prinsip ilmu dalam kehidupan, sebenarnya telah dilaksanaan sejak lama, yaitu mulai dari kurikulum 1975, hanya namanya bukan KBK, tetapi Kurikulum yang berorientasi pada tujuan. Kalau memperhatikan cara perumusan tujuannya, yang pada waktu itu disebut Tujuan Instruksional. Perumusannya sama, menekankan perilaku atau performansi yang dapat diamati atau diukur, menggunakan kata kerja operasional. Perumusan kompetensi ilmu pun tidak jauh berbeda, menggambarkan perilaku yang dapat diamati, menggunakan kata kerja operasional.

Kalau begitu apa yang barunya dari pendekatan kompetensi ini? Hal baru yang ingin ditekan oleh pendekatan kopetensi adalah dalam aplikasi konsep dan prinsip ilmu tersebut, hendaknya lebih intensif, lebih luas dan mencakup tahap-tahap berpikir yang lebih tinggi. Dengan mengikuti 
tahap-tahap berpikir atau tahap kognitif dari Benyamin Bloom dan kawan-kawan, pembelajaran tidak berhenti pada tahap pengetahuan dan pemahaman, tetapi dilanjutkan pada tahap aplikasi, analisis-sintesis, evaluasi dan kreativitas. Tahap-tahap kognitf dari Bloom dkk, telah disempurnakan oleh Lorin W. Anderson dan David R. Krathwohl tahun 2001, menjadi: pengetahuan, pemahaman, aplikasi, analisis (sintesis), evaluasi dan kreativitas.

Dalam pelaksanaan kurikulum selama ini, proses pembelajaran masih terbatas pada pengembangan kemampuan berpikir tahap rendah, yaitu tahap pengetahuan dan pemahaman. Kemampuan berpikir tahap aplikasi, analisis, sintesis, dan evaluasi sedikit sekali bahkan sangat jarang dijamah. Penerapan KBK dalam program pendidikan umum, lebih diarahkan kepada menegaskan kembali hal itu. Kurikulum dan pembelajaran diarahkan kepada penguasaan kompetensi atau kemampuan berpikir tahap tinggi. Proses pembelajaran tidak berhenti pada penguasaan pengetahuan (ingatan) dan pengertian (pemahaman), tetapi dilanjutkan kepada tahapan yang lebih tinggi, yaitu aplikasi, analisis, sintesis, dan evaluasi.

Dalam pelaksanaannya masih terbatas kepada pengembangan ke- mampuan berpikir tahap rendah, yaitu tahap pengetahuan dan pemahaman. Kemampuan berpikir tahap aplikasi, analisis, sintesis, dan evaluasi sedikit sekali bahkan sangat jarang dijamah.

Penerapan KBK dalam program pendidikan akademik, lebih diarahkan kepada menegaskan kembali hal itu. Kurikulum dan pembelajaran diarahkan kepada penguasaan kompetensi atau kemampuan berpikir tahap tinggi. Proses pembelajaran tidak berhenti pada penguasaan pengetahuan (ingatan) dan pengertian (pemahaman), tetapi dilanjutkan kepada tahapan yang lebih tinggi, yaitu aplikasi, analisis, sintesis, dan evaluasi. Tahap-tahap berpikir dari Bloom ini telah disempurnakan oleh Lorin W. Anderson dan David R. Krathwohl (2001), menjadi: pengetahuan, pemahaman, aplikasi, analisis (sintesis), evaluasi dan kreativitas.

Oleh karena itu dalam pelaksanaan KBK diharapkan digunakan pendekatan-pendekatan pembelajaran yang lebih mengaktifkan siswa, seperti pembelajaran: diskaveriinkuiri, bermakna, kontekstual, ekseriensial, komunikatif, pemecahan masalah, pengamatan lingkungan, percobaan, penelitian sederhana, simulasi, bermain peran, praktik langsung, dsb.

\section{Daftar Pustaka}


ISSN :-

Inovasi Kurikulum, Februari 2004, Thn.1, Vol. 1 Nomor : 1

Longstreet, W.S., dan Shane, H.G., (1993). Curriculum for a New Millennium. Boston: Allyn and Bacon

McNeil, J.D., (1985). Curriculum: A Comprehensive Introduction. Boston: Little, Brown and Company

Miller, J.P., and Seller, W., (1985). Curriculum: Perspectives and Practice. New York: Longman

Oliva, P. E., (1992). Developing the Curriculum. New York: Harper Collins Publishers

Saylor, J.G., et al. (1981). Curriculum Planning for Better Teaching and Learning. New York: Holt, Rinehart and Winston

Sukmadinata,N.Sy. (2003). Pengembangan Kurikulum: Teori dan Praktek. Bandung: Remaja Roosdakarya

\footnotetext{
-.---- (2002). Pengendalian Mutu Pendidikan Sekolah Menengah. Bandung: Kesujma Karya.

--ongendalian Mutu Pendidikan Sekolah Dasar. Bandung: Kesujma Karya. (dalam proses peneritan). Kurikulum dan Pembelajaran Kompetensi. Bandung: Remaja Rosdakarya.
} 